\title{
MICROBIAL MAT-RELATED STRUCTURES IN THE QUATERNARY CAPE VANI MANGANESE-OXIDE (-BARITE) DEPOSIT, NW MILOS ISLAND, GREECE
}

\author{
STEPHANOS P. KILIAS \\ Department of Economic Geology and Geochemistry, Faculty of Geology and Geoenvironment, \\ National and Kapodistrian University of Athens, Athens, 15784, Greece \\ e-mail:kilias@geol.uoa.gr
}

\begin{abstract}
Microbial mat-related sedimentary structures are present in Lower Pleistocene mixed epiclastic-volcaniclastic sediments that host the Cape Vani manganese-oxide (-barite) deposit on NW Milos Island, Greece. Milos Island is a dormant and recently emergent 2 Ma volcano of the active Southern Aegean volcanic arc. The deposit occurs in a 1-km-long marine rift basin floored by a dacite dome. Basin fill is a $>60-\mathrm{m}$-thick sequence of epiclastic glauconite-bearing sediments sandwiched between lower and upper mixed volcaniclastic sandy tuffs and epiclastic sandstones. Host siliciclastics consist of glass shards, lithic fragments, plagioclase, K-feldspar, biotite, pyroxene, and silica and clay cements, overprinted by a baritesilica-K-feldspar-illite assemblage. Manganese (IV)-oxide minerals include dominantly $\delta-\mathrm{MnO}_{2}$ (vernadite), hollandite group minerals, pyrolusite, ramsdellite, and nanocrystalline todorokite. Microbially induced structures occur in a specific lithofacies referred to as upper "ferruginous and white volcaniclastic sandy tuffs/sandstones" and are characterized by: (1) planar and herringbone cross-bedding, (2) small-scale, vertical fining-upward sequences, (3) flaser, wavy, and lenticular bedding, (4) marine trace fossils similar to Skolithos, and (5) beveling of ripple marks and desiccated silicified mudstone beds. These features, together with the microbially induced structures and the widespread presence of glauconite, reflect a littoral to tidal-flat paleoenvironment. The microbial mat-related sedimentary structures developed in the Mn-oxide ore formation are recognized as: (1) mat-layer structures, (2) growth bedding structures and nodules, (3) wrinkle structures and exfoliating sand laminae, (4) cracks with upturned and curled margins, (5) roll-up structures, (6) fossil gas domes, (7) mat fragments and chips, and (8) mat slump structures, suggesting photoautotrophic, possibly cyanobacterial, mats. The ubiquitous presence of barite, in the host sediments, in the mat-related structures, in feeder-vein and bedding conformable layers, and in the gravel unit that caps the Cape Vani sedimentary rocks, suggests that microbial mats were developed in association with white smokers acting as Mn(II) suppliers, in a sunlit shallow-water or tidal-flat paleogeothermal system. The intimate relationship of Mn(IV)-oxide ore mineralization with the microbial mat-related sedimentary structures, coupled with the presence of $\mathrm{Mn}$ mineralized microbial fossils in the ore, strongly suggests the possible role of bacterial photosynthesis in Mn(II) bio-oxidation and Mn(IV)-oxide biomineralization at Cape Vani. It is envisaged that most Mn(IV)oxide mineralization was synsedimentary and syngenetic and formed due to an interplay among shallow-marine/tidal-flat sedimentation, hydrothermal seafloor to subaerial hot spring activity, which provided $\mathrm{Mn}(\mathrm{II})$, and active, possibly photosynthetic, microbial activity. Chemotrophic influence on Mn(IV)-oxide biomineralization cannot be excluded.
\end{abstract}

KEY wORDs: biogenic Mn-oxides, fossil microbial mats, Cape Vani, Milos, barite white smokers

\section{INTRODUCTION}

Manganese (IV)-oxide minerals, abundant in both marine and terrestrial environments, are thought to form either directly by bacterial and fungal catalysis of the oxidation of water-soluble dissolved $\mathrm{Mn}(\mathrm{II})$ to form solid-phase Mn(IV)-oxides or by abiotic catalysis on the reactive biogenic Mn-oxide surface (Tebo et al. 2004). In spite of their recognized importance in global biogeochemical cycles, relatively little is known about the mechanisms and products of Mn-oxide biomineralization, and major questions concerning the origin of natural Mn-oxides remain unanswered. Current knowledge on bacteriogenic Mn-oxides is based largely on synthetic model oxides (Tebo et al. 2004, Spiro et al. 2010). Documentation or linkage of microbial mediation of natural Mnoxide accumulation is scarce and limited to freshly precipitated (within days) seafloor hydrothermal Mn-oxides from the Guaymas Basin deep-sea hydrothermal plume, Gulf of California (Dick et al. 2009), Quaternary Mn-rich hot-water travertine deposits, Morocco (Chafetz et al. 1998), Lower Cretaceous Mn-oxide ores in sandy claystones, Groote Eylandt, northern Australia (Ostwald 1981, 1990), or Late Paleoproterozoic oncolitic Mn ores in alluvial red beds, Bronkhorstfontein, South Africa (Gutzmer et al. 2002). In the Californian and South African examples, Mn biomineralization is inferred on the basis of mineralogical, geochemical, and biogeochemical studies, whereas a spatial relationship of microbially induced geological structures to the Mn mineralization (i.e., Mn-rich shrubs) has been found only in the thermogene travertines in Morocco (Chafetz et al. 1998), and Mn mineralized microfossils have been found in the Australian ores (Ostwald 1981, 1990). The present study reports structures in the Cape Vani Mn-oxide(-barite) deposit, NW Milos, Greece, that developed on hydrothermally turbated siliciclastic/epiclastic sandstone and sandy tuff host rocks, and the $\mathrm{Mn}$ ore, which bear striking similarities to ancient and modern photoautotrophic microbially induced sedimentary structures (MISS) (Noffke et al. 2001, Noffke 2010) or "mat-related structures" (MRS) (Schieber et al. 2007). A geobiological relationship between Mn-oxide biomineralization and photoautotrophy is proposed.

\section{REGIONAL AND LOCAL GEOLOGICAL SETTING}

\section{General Setting}

Milos is a recently emergent 2 Ma volcano of the Pliocenemodern Southern Aegean volcanic arc (Fig. 1). The island is composed of late Pliocene submarine volcanic deposits and late Pleistocene to Holocene subaerial volcanic deposits, which overlie Miocene and Lower Pliocene carbonate sedimentary successions (Fytikas et al. 1986, Stewart and McPhie 2006). The volcanic rocks are calc-alkaline, predominantly andesites and lesser dacites. Milos has an active high-enthalpy geothermal system that vents in the shallow $(<100 \mathrm{~m})$ marine and terrestrial environments (Valsami- 


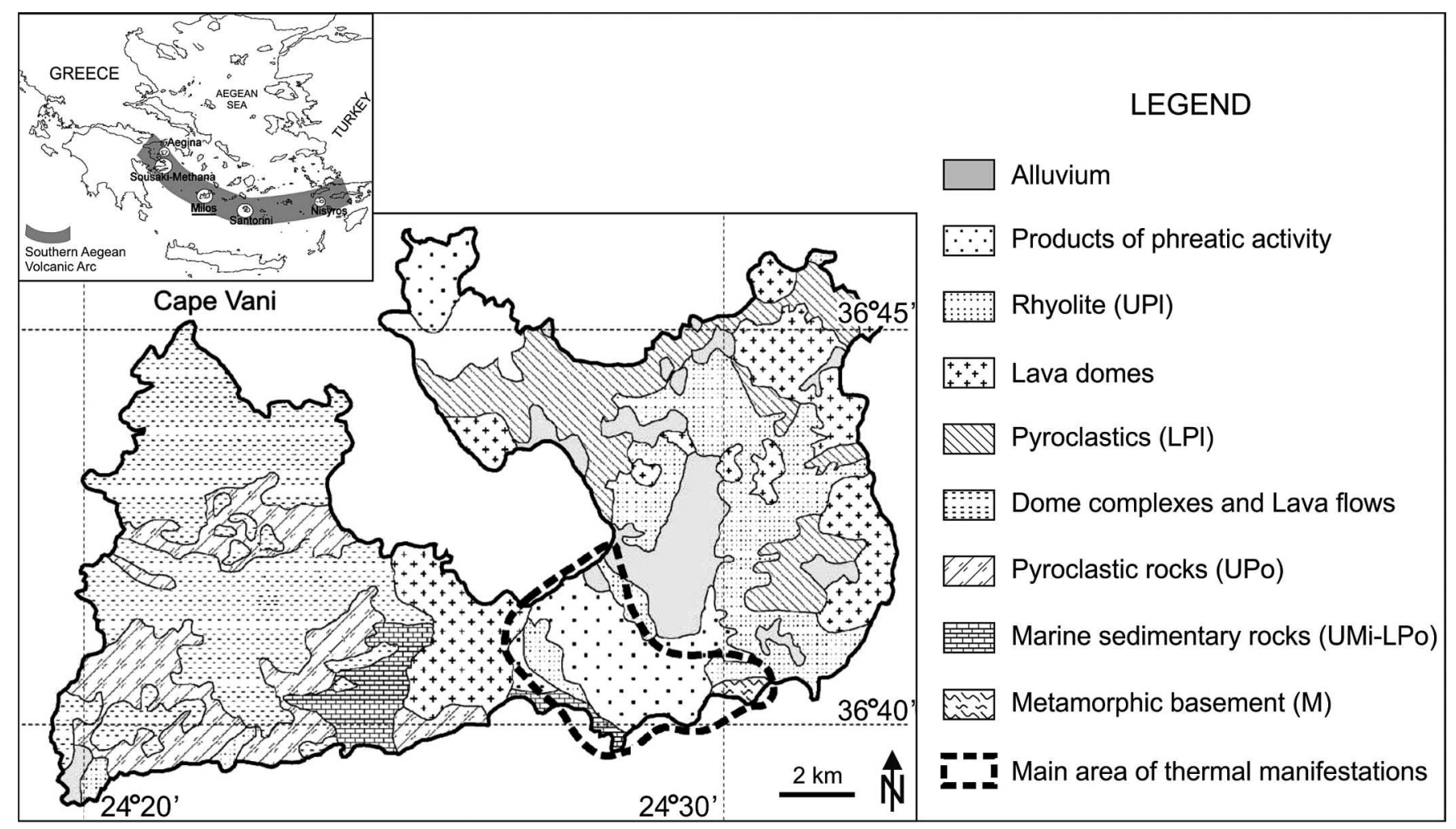

FIG. 1.- Main geologic features of Milos Island and location of Cape Vani, and main surface manifestations of active geothermal system. Inset shows Milos and volcanic centers along the Southern Aegean volcanic arc. UPI-Upper Pleistocene; LPl—Lower Pleistocene; UPo-Upper Pliocene; LPo_-Lower Pliocene; UMi-Upper Miocene; M-Mesozoic (Milos map adapted from Fytikas et al. 1986).

Jones et al. 2005), and the island as a whole has been hydrothermally active for around 1.5 Ma (Fig. 1). Recent research has identified a new metallogenic environment-namely, mineralization and geothermal activity associated with emergent volcanoes. Driven by magmatic heat, sea, meteoric, and magmatic waters mix to produce geothermal systems that give rise to hybrid volcanic-hosted massive sulfide (VMS) and continental epithermal mineralization (Kilias et al. 2001, Naden et al. 2005), and a diverse, submarine to terrestrial suite of young and extremely well-preserved mineralized paleogeothermal systems. The latter are best represented by the Cape Vani Mn-Ba deposit, on NW Milos (Fig. 1). It is viewed as a stratabound Mn deposit formed by subseafloor replacement of porous volcaniclastic rocks (Hein et al. 2000, Glasby et al. 2005), diagenetic processes (Skarpelis and Koutles 2004), and submarine hot springtype processes (Plimer 2000). The following description, based on Kilias et al. (2007), incorporates basic geological data from previous workers (Hein et al. 2000, Liakopoulos et al. 2001, Skarpelis and Koutles 2004) and presents some new data.

\section{Cape Vani Deposit}

The Cape Vani deposit occurs in a 1-km-long marine rift basin that was developed in a footwall of an andesitic lava dome. The basin is filled with $>60$-m-thick siliciclastic sediments composed of Upper Pliocene-Lower Pleistocene epiclastic glauconite-bearing sediments, sandwiched between lower and upper mixed volcaniclastic sandy tuffs and epiclastic sandstones (see Fig. 2).

The volcaniclastic rocks are thinly bedded to laminated friable porous sandy tuffs and sandstones. The principal components of the sandy tuff are highly vesicular altered pumice and lithic fragments, grains of K-feldspar, altered volcanic glass, pyroxene, and subordinate quartz and clays. The glauconitic epiclastic rocks are massive to thinly bedded sandstones, composed predominantly of crystals of sericitized plagioclase, K-feldspar and chloritized biotite, hydrated or feldspathized vitric clasts, glauconite, and minor dacitic to andesitic lithic clasts, biogenic clasts, and silica and clay mineral cements. It should be stressed that glauconite is not restricted to this stratigraphic level but is a common minor constituent throughout the basin fill as an authigenic precipitate in the form of pore fillings (Skarpelis and Koutles 2004).

In the upper part of the sedimentary succession, the sandy tuff is Ferich, grading vertically into white sandy tuff. The section is unconformably overlain by a massive gravel with principal components made of clasts of dacite, andesite, colloform banded quartz and jaspilitic chert, and fragments of sandstone and sandy tuff, and barite. The gravel unit is capped by a cherty mudstone with desiccation cracks.

Veins, interpreted as feeder structures and consisting chiefly of banded open-space fillings of barite, minor colloform quartz, goethite, Fe-hydroxides, and X-ray amorphous hollandite group-like minerals and $\mathrm{MnO}_{2}$-like phases, crosscut the epiclastic/volcaniclastic succession and the underlying lavas and hyaloclastite for several tens of meters below the sedimentary deposits (Fig. 2). With the exception of the abundant barite, these veins are typical epithermal-type veins, which display complex multi-episodic filling with textures characteristic of void-fill precipitation (Hedenquist et al. 2000). Exhalative barite-rich deposits characteristic of seafloor venting, with white 

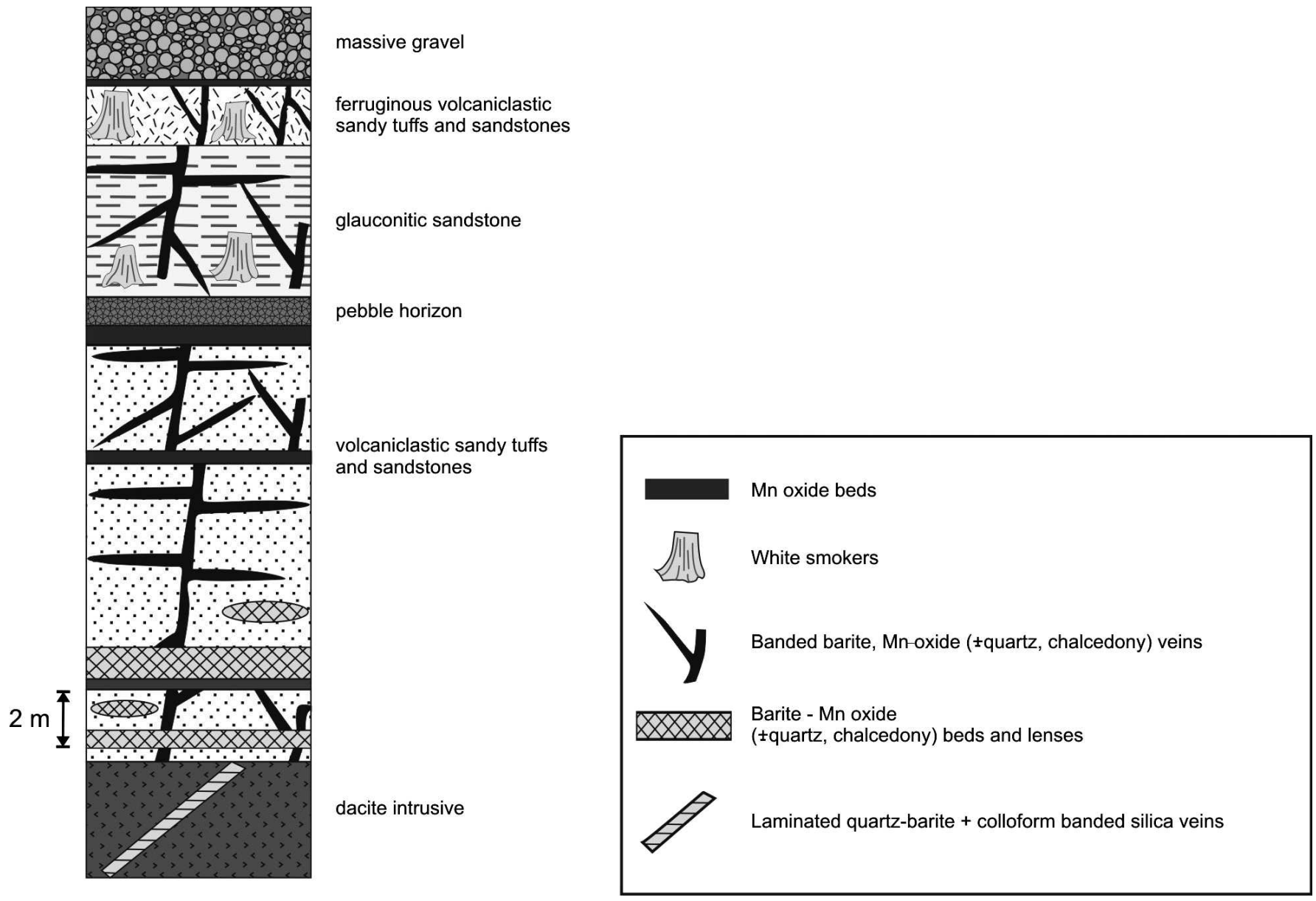

FIG. 2.-Schematic inferred lithostratigraphic section of Cape Vani Mn-Ba deposit (modified after Liakopoulos et al. 2001, Hein et al. 2000).

smoker (sulfate)-like structures, occur preserved in the epiclastic glauconite-bearing sedimentary strata. In addition, bedding-conformable barite-Mn-oxide(-quartz, chalcedony) layers, and lenses with grossly the same mineralogy, as well as pebble layers, occur preserved in the epiclastic/pyroclastic succession (Fig. 2). The white smoker structures, the feeder veins, and the bedding-conformable layers have been considered analogous to deposits formed from modern lowtemperature seafloor venting hydrothermal systems (e.g., Pirajno and Van Kranendonk 2005, Harris et al. 2009). This is corroborated by fluid inclusion microthermometry of barite and quartz, which indicates boiling fluids exhaling on the paleo-seafloor at temperatures around $100^{\circ} \mathrm{C}$ (Kilias et al. 2007).

Despite extensive faulting, microbially induced structures occur in specific lithofacies, namely, ferruginous and white volcaniclastic sandy tuffs and sandstones characterized by distinct sedimentary structures, such as (Fig. 3): (1) planar and herringbone cross-bedding, (2) smallscale, vertical fining-upward sequences, (3) flaser, wavy, and lenticular bedding, (4) marine trace fossils similar to Skolithos (Bromley and Asgaard 1991), and (5) beveling of ripple marks, which are capped by silicified mudstone beds with intensive desiccation (see Fig. 3). These sedimentary structures support a shallow-marine to shoreline depositional setting characterized by tidal influence (e.g., Dashtgard et al. 2009, Noffke 2010). Furthermore, the presence of glauconite throughout most of the basin fill may be used as an indicator of very shallow-marine to tidal-flat conditions of sedimentation (e.g., Chafetz and Reid 2000). All the sedimentary lithologies are overprinted by a silica-K-feldspar-illite-barite assemblage, probably as a result of submarine diagenetic alteration due to heat-driven fluid flow (Skarpelis and Koutles 2004), and/or seafloor hydrothermal alteration (Liakopoulos et al. 2001)

The Mn-oxide deposits exhibit a range of deposit styles: (1) $\mathrm{Mn}(-\mathrm{Fe})$ crusts, (2) Mn sandstone/sandy tuff, (3) stratiform Mn, (4) Mn cobble deposits, and (5) stringer Mn deposits. For details of deposit styles of the Mn-oxide deposits, see Hein et al. (2008) and Kilias et al. (2007), and for descriptions of the mineralogy, see Liakopoulos et al. (2001), Hein et al. (2000), and Kilias et al. (2007). Manganese minerals include dominantly $\delta-\mathrm{MnO}_{2}$ and $\delta-\mathrm{MnO}_{2}$-like phases, hollandite group minerals, pyrolusite, ramsdellite, romanechite-like minerals, and nanocrystalline todorokite.

\section{STRUCTURES OF MICROBIAL MAT-RELATED ORIGIN}

Myriad structures, interpreted here to be of microbial mat origin, occur on bed surfaces and on bed interfaces of the upper sandy tuff/ sandstone facies of the basin fill in Cape Vani. Described next, these structures are grouped under the terms "microbially induced sedimentary structures" (MISS; Noffke et al. 2001, Noffke 2010) or "microbial mat-related structures" (MRS) (Schieber 2004). Unless otherwise noted, I use a combination of the classification schemes of 

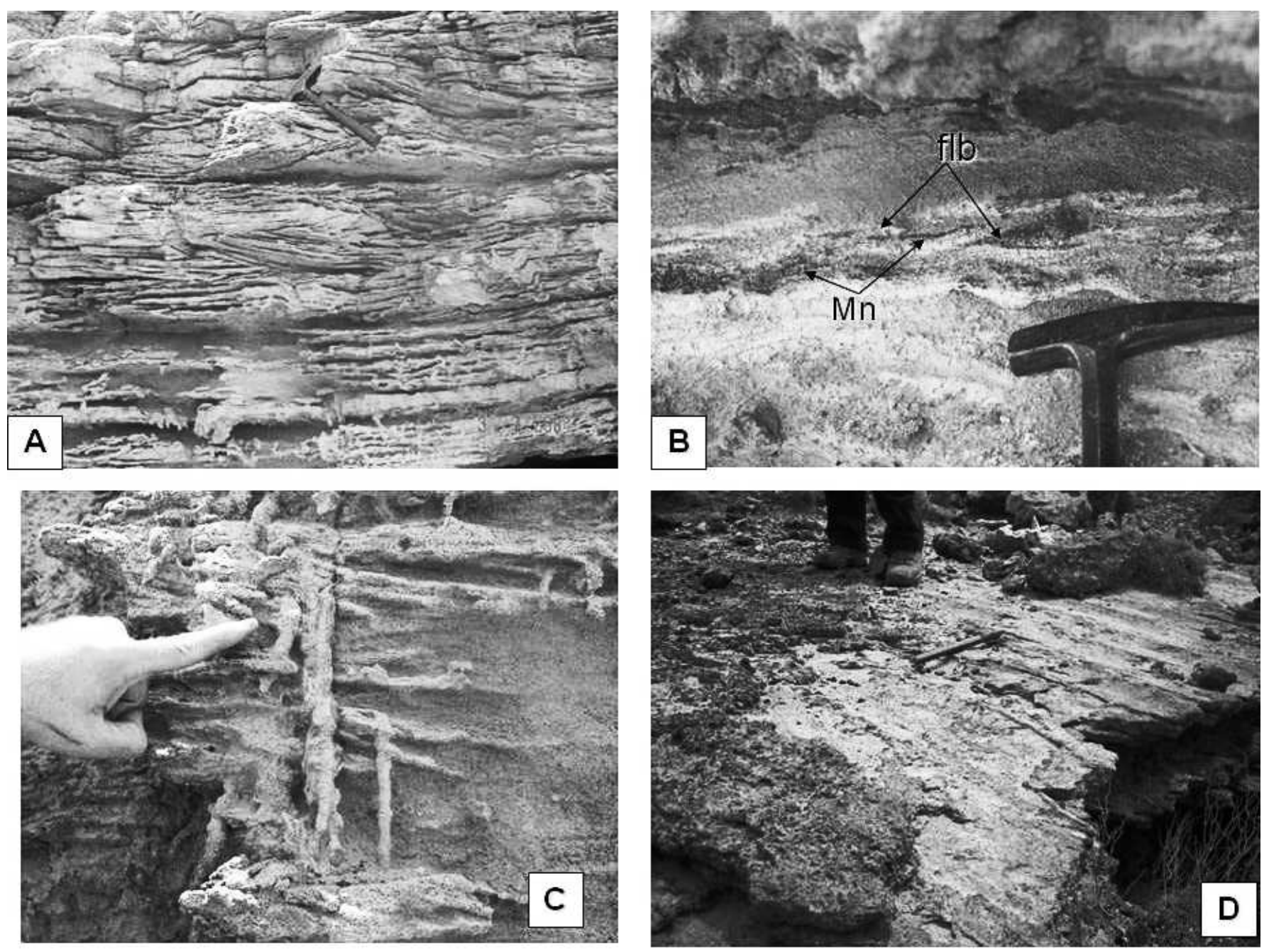

FIG. 3.-Volcaniclastic sandy tuff/sandstone facies, which occur principally in the upper parts of the basin fill at Cape Vani. (A) Cross-section view demonstrating planar and herringbone cross-beds. Hammer is $32 \mathrm{~cm}$ long. (B) Cross-section showing ripple-laminated tuffaceous sandstone passing upward into flaser and lenticular bedding (flb). Sand ripples are accentuated by thin Mn-oxide laminae (black) (Mn). Hammer head is $16 \mathrm{~cm}$ long. (C) Assemblage of marine trace fossils including Skolithos. (D) Rippled surface of tuffaceous sandstone is overlain by $\mathrm{Mn}$ sandstone showing microbial mat structure. Chisel is $21 \mathrm{~cm}$ long.

Schieber (2004), presented by Schieber et al. (2007), Noffke et al. (2001), and Noffke (2010).

\section{Mat-Layer Structure}

This structure consists of a 3- to 4-mm-thick sheet-like layer on top of a nonmineralized sandstone bed surface; it is massive and has a flat nonerosional base (Fig. 4A, B). In plan view, it consists of clusters of elongated, lenticular, curved to sinuously curved, spindle-like edifices of $\mathrm{Mn}$ sandstone/sandy tuff (Fig. 4A, B). These edifices have maximum length and width of 15 and $3 \mathrm{~cm}$, respectively, and consist of a median groove flanked on both sides by thin, 2- to 3-mm-high steep ridges, which usually have a tapering termination at one or both ends of the structure. The spindle-like structures occur: (1) as discrete, randomly arranged spindles, which either crosscut or have no apparent relationship to neighboring ones; (2) as dense networks and bodies of spindles with variable shape, size, and organization, and no definite geometry; and (3) as multiple tightly packed spindles in apparently scale-like, concentric development with a crenulated appearance forming locally discoid (diameters range from 15 to $30 \mathrm{~cm}$ ) surface morphologies (Fig. 4A, B). The occurrence style (2) may form the cores of the discoid morphologies (Fig. 4B). In general, spindle-like structures tend to crosscut each other, showing complex overlapping relationships. The surface of the structure is irregularly ornamented with millimeter-scale Mn-oxide-sandstone bulges, and structures with nodular or cauliflower-like surface fabric (Fig. 4A, B).

Interpretation: The only published structures that resemble these Cape Vani structures are those Sarkar et al. (2008, their Fig. 5A) described as "mat-layer discoidal structures" from the Neoproterozoic Sonia Sandstone in India; they ascribed these structures to direct photosynthetic microbial mat growth origin. Alternatively, at least some of these spindle-like structures may represent spindle-shaped microbial shrinkage cracks (Eriksson et al. 2007, Noffke 2010), or trace fossils, and/or strong bioturbation by undermat burrowing 

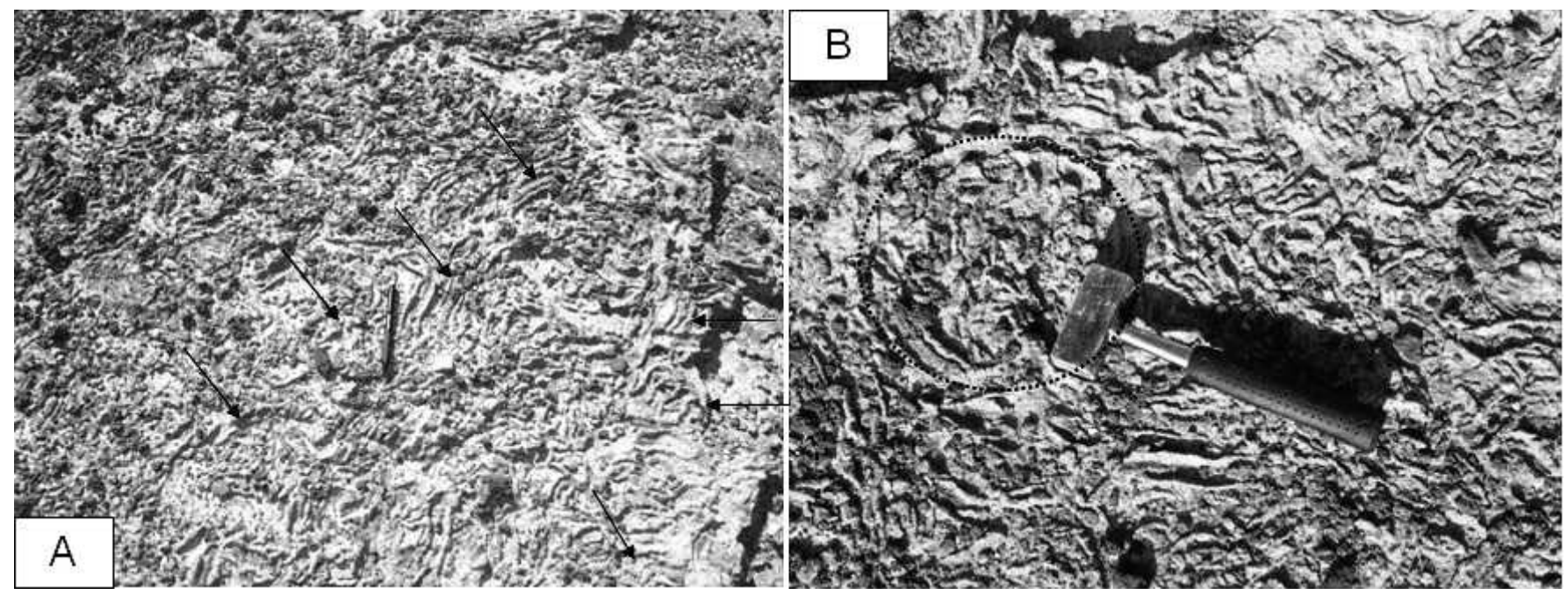

FIG. 4.- (A) Upper bedding surface showing "mat layer structure." Concentric rims have crenulated appearance (black arrows). (B) Close-up of A showing discoidal colony texture (dotted line).

organisms ("mat miners") (Dornbos et al. 2004; Bouougri and Porada 2007 a, p. 220). However, the generally steep flanks of the spindles distinguish these structures from mat miner trails (Sarkar et al. 2006).

\section{Growth Bedding Structures and Nodules}

Growth bedding structures (sensu Gerdes 2007) refer to resistant, horizontally layered, bedding-plane concordant, planar laminae, which characterize vertical sections through stratiform Mn-oxide deposits (Fig. 5A). Numerous loaf- to mound-shaped cauliflower-like protrusions consisting of hemispheroidal to spheroidal and botryoidal Mnoxide clusters decorate individual laminae surfaces or soles, or grow irregularly normal to bedding in interlaminae space (Fig. 5B). Individual discontinuous sinusoidal-shaped laminae up to $10 \mathrm{~cm}$ long are also visible in the sedimentary sequence (Fig. 5C).

Interpretation: The resistant planar laminae structure compares well with growth-bedding structures (Gerdes 2007; her Fig. 2-1-2[b] and [c] and Fig. 2-4-2), which are interpreted as stacks of microbial mats developed in an intertidal sedimentary paleoenvironment. The nodular structure is very similar to the thrombolytic fabric of Gerdes et al. (2000), and the nodular to biscuit-like structures of Gerdes (2007; her Fig. 2-1-3B and Fig. 2-1-4 G, H), and may be interpreted as the result of localized growth and cell division of coccoid cyanobacteria in a shallowwater peritidal environment (Gerdes et al. 2000, Gerdes 2007). Following Noffke et al. (2001), the sinusoidal structures indicate coating of buried rippled tidal surfaces by cyanobacterial mat laminae. The very selective occurrence of stratiform Mn-oxide mineralization at certain microbial mat-related stratigraphic horizons is strongly suggestive of mat-related biomineralization (Schieber 1999).

\section{Wrinkle Structures and Exfoliating Sand Laminae}

Minuscule sub-millimeter-thick successive veneers of Mn-oxide crusts with crinkled surface morphologies and associated exfoliating sand laminae structure occur, though rarely, on top of Mn sandstone/ sandy tuff bed surfaces (Fig. 6). Two types of associated wrinkle structures have been observed: (1) The overlying thin $(<1 \mathrm{~mm})$ veneer (A in Fig. 6) of Mn-oxide crust, which seems to spall off a subjacent wrinkled Mn crust, is characterized by a reticulate pattern of cushion- like crests and sharp valleys of irregular directions; and (2) the immediately subjacent Mn-oxide crust veneer (B in Fig. 6) does not replicate the same wrinkles; the latter forms an irregular mosaic pattern composed of irregular 10- to 20-mm-long, round-crested, microripplelike meandering and partly interfering ridges about $1 \mathrm{~mm}$ high, and intervening rather flat troughs or pits (Fig. 6). These structures belong to the "non-transparent wrinkle structures" (sensu Noffke 2000), because the original physical relief of the bedding plane is not visible beneath the wrinkles.

Interpretation: Wrinkle structures on sandstones have been diversely attributed to either biotic or abiotic processes (e.g., Noffke et al. 2002, Bottjer and Hagadorn 2007). Analogous wrinkle structures and associated "peeling off" structures, preserved in Late Cambrian quartz arenites, were described as "old elephant skin," or OES and associated with exfoliating sand laminae structure by Bottjer and Hagadorn (2007; see caption in their Fig. 4(a)-8, p. 62). They interpreted this feature (in the absence of mudstone) to the presence of a biofilm on each layer, which inhibited amalgamation of the underlying layer into the newly deposited overlying layer. Certain wrinkle structures in the geologic record are considered to represent in situ fossilized photoautotrophic microbial mats (Noffke 2010, p. 131, 134). Furthermore, the association of in situ photoautotrophic microbial mats with Mn-oxide mineralization strongly suggests that the growth of photosynthetic microbial mats on and within the paleosediment surfaces and deposition of the Mn crusts occurred during the same period and were genetically related. Manganese biomineralization of the buried organic matter supports the preservation of microbial mat fabrics, and the excellent preservation of microbial mat fabrics strongly corroborates this notion (Noffke et al. 2002).

\section{Cracks with Upturned and Curled Margins}

Subcircular or linear positive features, which consist of irregular inward-convex, or steep, Mn sandstone/sandy tuff ridges, occur on $\mathrm{Mn}$ sandstone/sandy tuff bed surfaces (Fig. 7A-C). Their heights vary between a few millimeters to $3 \mathrm{~cm}$, and they are ornamented with a nodular surface. The diameters of the subcircular structures range from 10 to $30 \mathrm{~cm}$, and lengths of straight ridges may reach $2 \mathrm{~m}$.

Interpretation: The structures presented here can be identified quite 


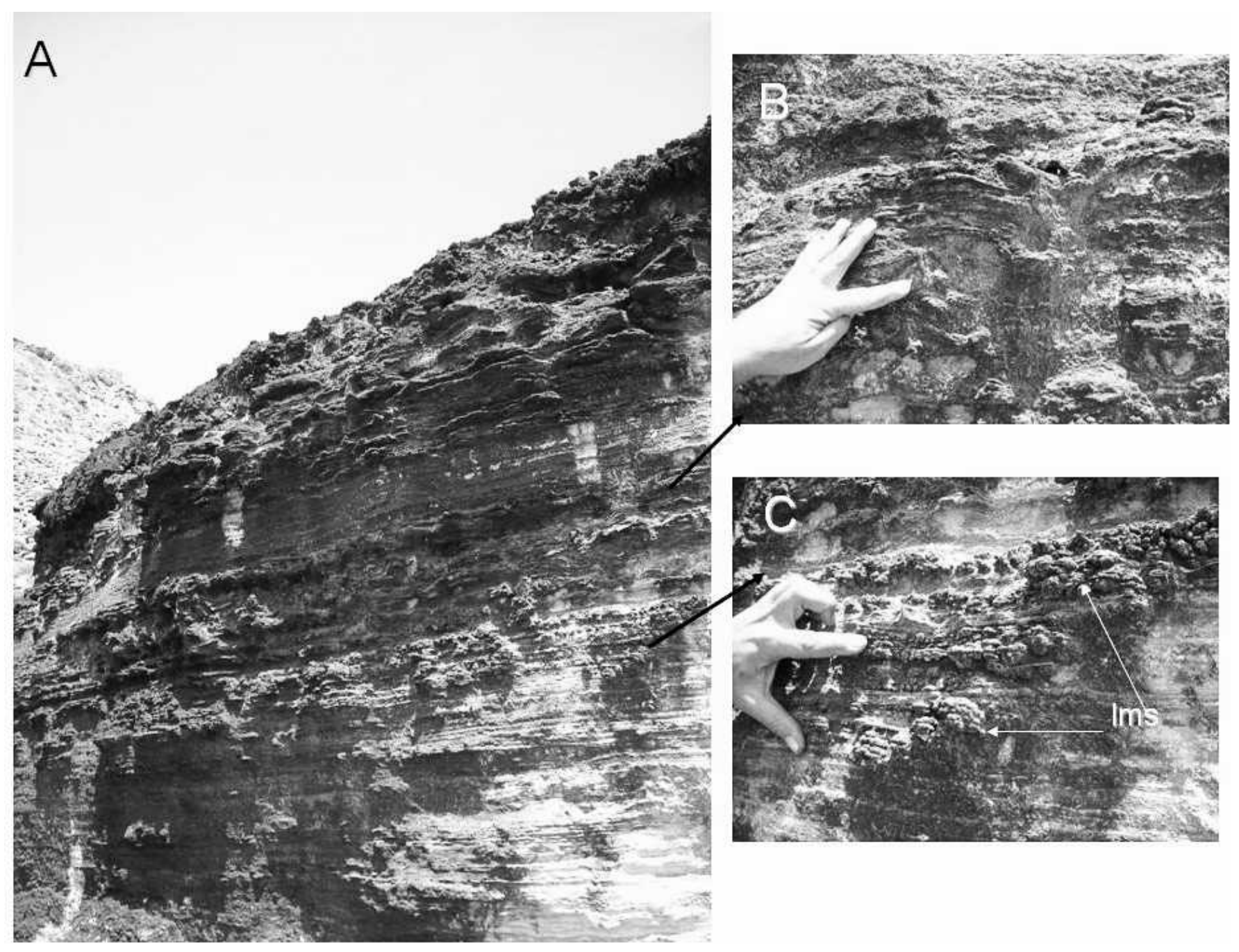

FIG. 5.-Growth bedding and nodules in 5-m-high cliff face through tidal sandstone/sandy tuff hosting stratiform Mn ore of the abandoned Cape Vani mine. (A) Laterally extensive and resistant planar laminae of stratiform Mn with growth bedding structure. Stratiform nodular Mn deposits, partly with flaser bedding, pass upward into parallel-laminated sandy tuff/sandstone and thence into the growth bedding structure. (B) Sinusoidal structure. Ripple laminated stratiform Mn ore, possibly indicating buried cyanobacterial mat laminae. (C) Unlaminated to poorly laminated loaf- to mound-shaped structures (lms) with a macroscopic pustular and/or cauliflower-like thrombolytic fabric.

confidently as "curled crack margins" (Eriksson et al. 2007, their Fig. $4[\mathrm{c}]-5)$. Such structures have been interpreted as the preserved involute(curled) margin of linear cracks and subcircular cracks and openings in a thin microbial mat, or mat chip, developed on a sandy sediment surface as a result of the combined action of shrinkage and cracking of the mat top surface in peritidal coastal plains (Eriksson et al. 2007). Furthermore, the nodular surface of the ridges supports participation of coccoid cyanobacteria in the construction of this pattern (e.g., Gerdes 2007).

\section{Roll-Up Structures}

Overfolded structures consisting of rolled-up concentric thin Mn crusts, or thin stratiform Mn layers, occur at several stratigraphic levels, or on bed surfaces, in thinly bedded Mn sandstone/sandy tuff, or
Mn cobble deposits (Fig. 8). These structures have dimensions of a few square centimeters up to $\sim 1 \mathrm{~m}^{2}$, and they are oval, ovoid, or lensshaped. Usually, they occur concentrated in narrow stratigraphic zones. Various varieties of roll-up structures occur: (1) flattened concentric roll-ups (Fig. 8A, D); (2) ridge-like roll-ups, $\sim 2$ to $3 \mathrm{~cm}$ high, which are parts of upturned crack margin structures (Fig. 8B); and (3) unflattened concentric roll-ups, either illustrating "cigar-like" threedimensional geometry (Fig. 8C), or circular to ovoid in cross-section (Fig. 8D). Associated mat deformation structures, such as mat slump structures (Porada and Bouougri 2007, p. 141), occur as thin Mn-oxide layers with a crescentic wavy structure (Fig. 8D).

Interpretation: Several publications describe similar fossil roll-up structures from shallow-marine microbially induced sedimentary structures; e.g., from Paleozoic and Precambrian tidal and shelf sandstones (Noffke 2000, Noffke et al. 2006), Precambrian shelf quartz 


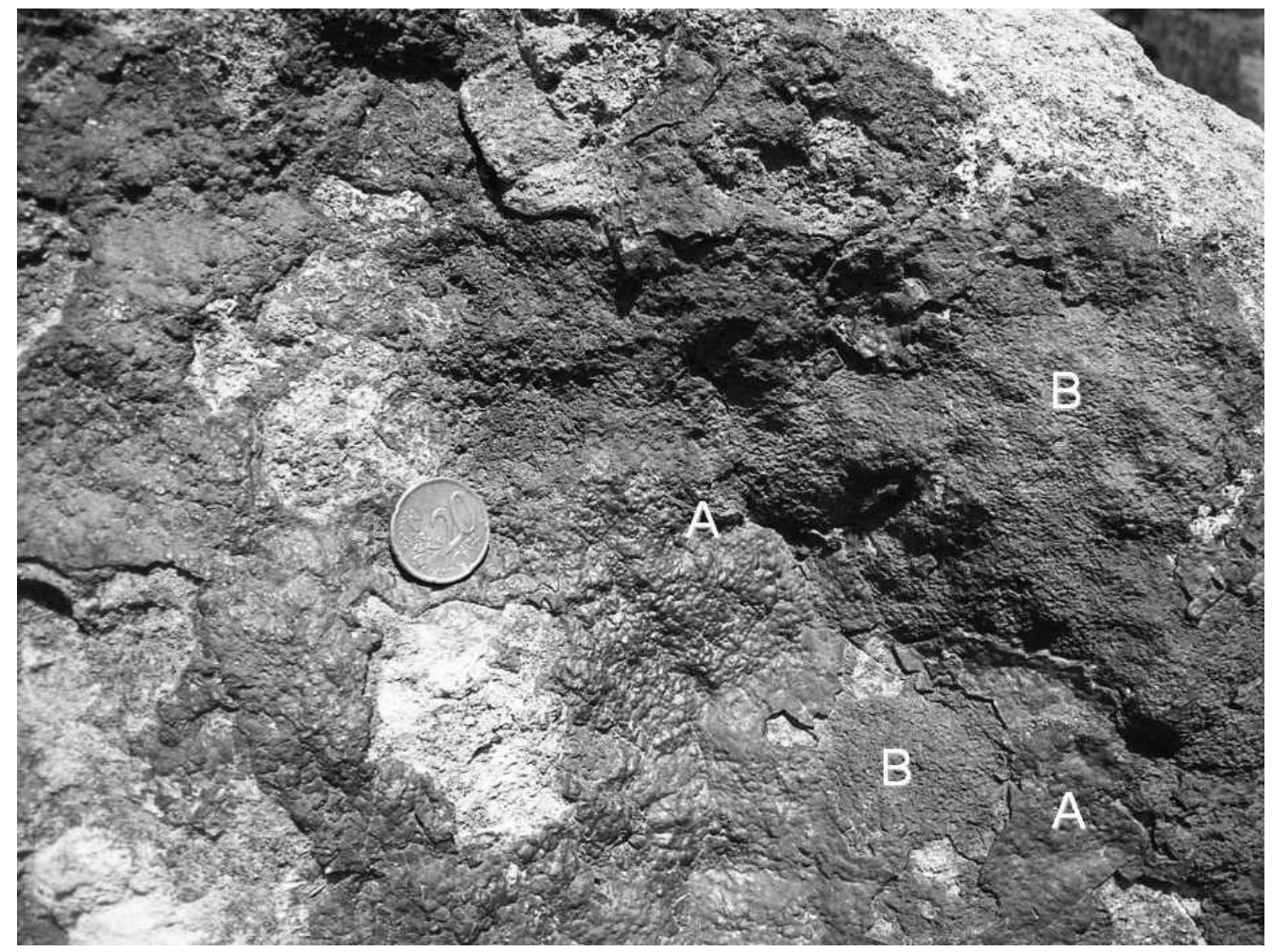

FIG. 6.-Wrinkle structures and exfoliating sand laminae structure. Very thin Mn crusts on upper bedding surface of sandstone/sandy tuff exhibit wrinkle structures and exfoliating sand laminae structure (see text for discussion). Coin is $2 \mathrm{~cm}$ diameter. Note that wrinkled texture on each layer (A) differs in arrangement from adjacent layers (B), indicating the presence of fossil biofilms.

sandstones and chert (see references in Noffke et al. 2006), and Cambrian-Ordovician quartz arenites (Donaldson and Chiarenzelli 2007), and playa and/or eolian sands (Eriksson et al. 2007). The roll-up structure in Figure 8B is similar to an analogous roll-up structure preserved in Early Archean fine-grained sandstone bed (Moodies Group, South Africa) depicted in Figure 2C of Noffke et al. (2006). In addition, analogous rolled up "cigar-like" mat fragments are documented by Eriksson et al. (2007). There is a general consensus that these structures result from contortion or warping of epibenthic microbial mats due to external physical or climatic influence acting upon the mat; a photoautotrophic origin for the mats cannot be excluded (Noffke et al. 2006, Eriksson et al. 2007, Noffke 2010). Mat slump structures imply internal cohesive strength, and it is suggestive of a microbial mat origin (Schieber et al. 2007); this interpretation is supported by the associated roll-up structures (Fig. 8D). Associated flame-like structures composed of Mn-oxides combined with load-cast sedimentary structures (Fig. 8D) are indicative of synsedimentary origin and are evidence for syngenetic Mn mineralization (Gutzmer et al. 2002).

\section{Fossil Gas Domes}

Hemispherical or roundly conical dome-like elevations with a central crater-like depression, as well as uncollapsed domal upheavals, which are round at their basis, project locally from otherwise planar Mn sandstone/sandy tuff bedding surfaces (Fig. 9). The bases of the domal features are 3 to $20 \mathrm{~cm}$ in base diameter, and the domes are 2 to $10 \mathrm{~cm}$ high (Fig. 9A, B). The edges of the domes characteristically grade into the surrounding sediment. Some collapsed domes exhibit very steep $>45^{\circ}$ circular flanks (Fig. 9B). Uncollapsed or collapsed domes may coexist on the same bed surface (Fig. 9B). Some unruptured domes are characterized by a macroscopic knobby or cauliflower-like growth fabric, which is due to numerous, tightly spaced and coalesced hemispheroidal lobes (botryoids) of various sizes (Fig. 9C). Tiny domal features with craters, and concentric spires resembling "complex structures associated with siliciclastic biolaminites" (Bouougri and Porada 2007b, p. 111), coexist on the same bed surface (Fig. 9D).

Interpretation: A very likely explanation for these elevated structures is that they originate from gases generated and accumulated underneath sediment-sealing microbial mats; generation of gases is due to decay of buried microbial mat in shallow-water (possibly tidal) sediments. It is the increasing gas pressure that lifts the microbial mat up, forming the domal structures. Very similar structures with the same dimensions have been described from modern, as well as ancient, MISS in tidal settings (e.g., Reineck et al. 1990, Sarkar et al. 2006, Gerdes 2007, Noffke et al. 2008, Bose and Chafetz 2009). Tiny domal features represent burst-open fossil blisters resulting from photosynthetic gas production due to subsurface metabolic effects (Gerdes 2007). In addition, similar cauliflower-like nodular growth fabrics, like the ones that ornament the Mn sandstone/sandy tuff gas domes described here, have been depicted from modern as well as ancient settings, and have been ascribed to biogenic mats constructed of coccoidal cyanobacteria (e.g., Gerdes et al. 2000, Gerdes 2007).

\section{Mat Fragments and Chips}

Deformed rigid segments of thinly laminated Mn crust, with highly irregular outlines and embayments, and millimeter-scale thickness, occur plentifully scattered across a large Mn sandstone/sandy tuff 

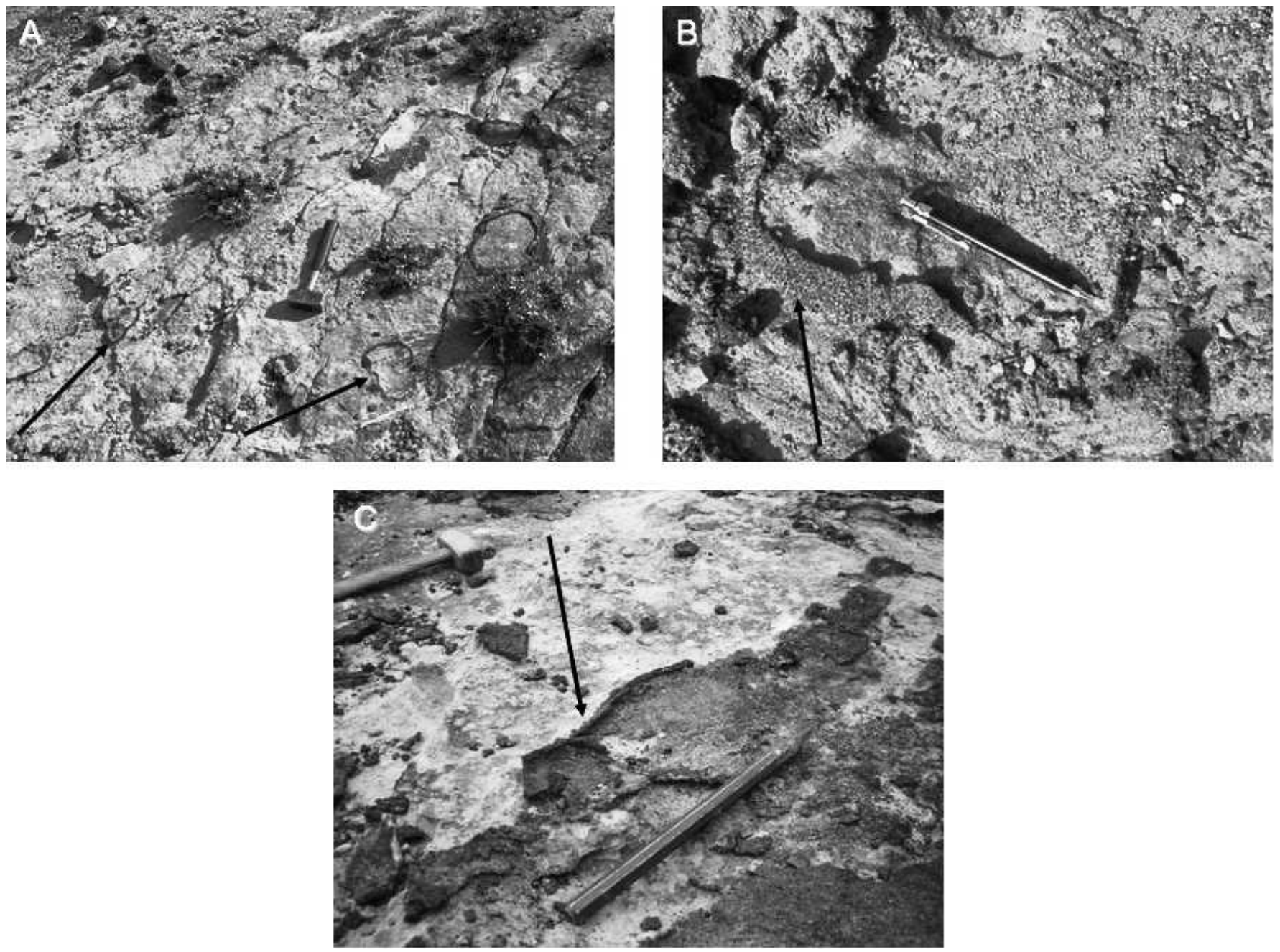

FIG. 7.-Cracks with upturned and curled margins on upper surface of fine-grained Mn sandstone/sandy tuff. (A) Irregular subcircular ridges are steep, inwardly convex, and crenulated. They may either be isolated or may coalesce into clusters of two or three structures (arrows). Hammer shaft is $23 \mathrm{~cm}$. (B) Nodular ridge (arrow). Pen is $17 \mathrm{~cm}$. (C) Curved and upturned (involute) margin (arrow) of inferred fossil microbial mat consists of Mn-rich sandstone. Chisel in $\mathrm{C}$ is $21 \mathrm{~cm}$.

bedding surface (see Fig. 10A, B). The maximum segment thickness is less than $5 \mathrm{~mm}$ and lateral extension is 1 to $2 \mathrm{~m}^{2}$. Ductile and brittle deformation is evident in the form of bending and overlapping hairline cracks, respectively (Fig. 10C, D).

Interpretation: These structures represent fossil, or recent, erosional remnants and pockets, and mat chips, formed by epibenthic microbial mats, in a tidal environment. They are strikingly similar in many aspects both to modern and fossil mat chips and erosional remnants (Noffke 2010, her Fig. IV.15).

\section{Possible Fossil Microorganisms}

Electron microscopy with backscattered electron imaging (SEMBSE) of samples of Mn-mineralized microbial mat-related structures, collected from the abandoned Cape Vani open pits, reveals Mnmineralized microstructures resembling fossil microorganisms (Kilias et al. 2007) (see Fig. 11). Sample chips were gold-coated after being cleaned in an ultrasonic bath and rinsed with acetone and dried, and they were studied on a JEOL 5600 scanning electron microscope (SEM) in the Department of Geology and Geoenvironment of the National and Kapodistrian University of Athens. These microstructures consist of small (1-5 $\mu \mathrm{m})$ spherical and rod-shaped cell-like structures (Fig. 11A), and branching filamentous constructions $(<60 \mu \mathrm{m}$ long $)$ (Fig. 11C); they are interpreted to be fossil coccoid and bacillary bacteria cell colonies, or filamentous microbes, embedded within extracellular polymeric substance (EPS) remnants, and/or phenomena associated with microbes (Fig. 11). This is chiefly based on the identification criteria of Westall and Folk (2003): (1) Geological plausibility: Shallow-marine/tidal and sunlit seafloor venting hydrothermal systems like Cape Vani are ideal environments for growth of bacteria under extreme conditions (Reysenbach and Cady 2001, Noffke 2010). (2) Size: Most of the microstructures fall within the size range of modern bacteria and cyanobacteria (Westall and Folk 2003). (3) Shape and cell-wall morphology: The spherical and rod-shaped structures, and the branching filamentous constructions have the morphological characteristics of modern Fe-Mn-oxidizing bacteria (Reysenbach and 

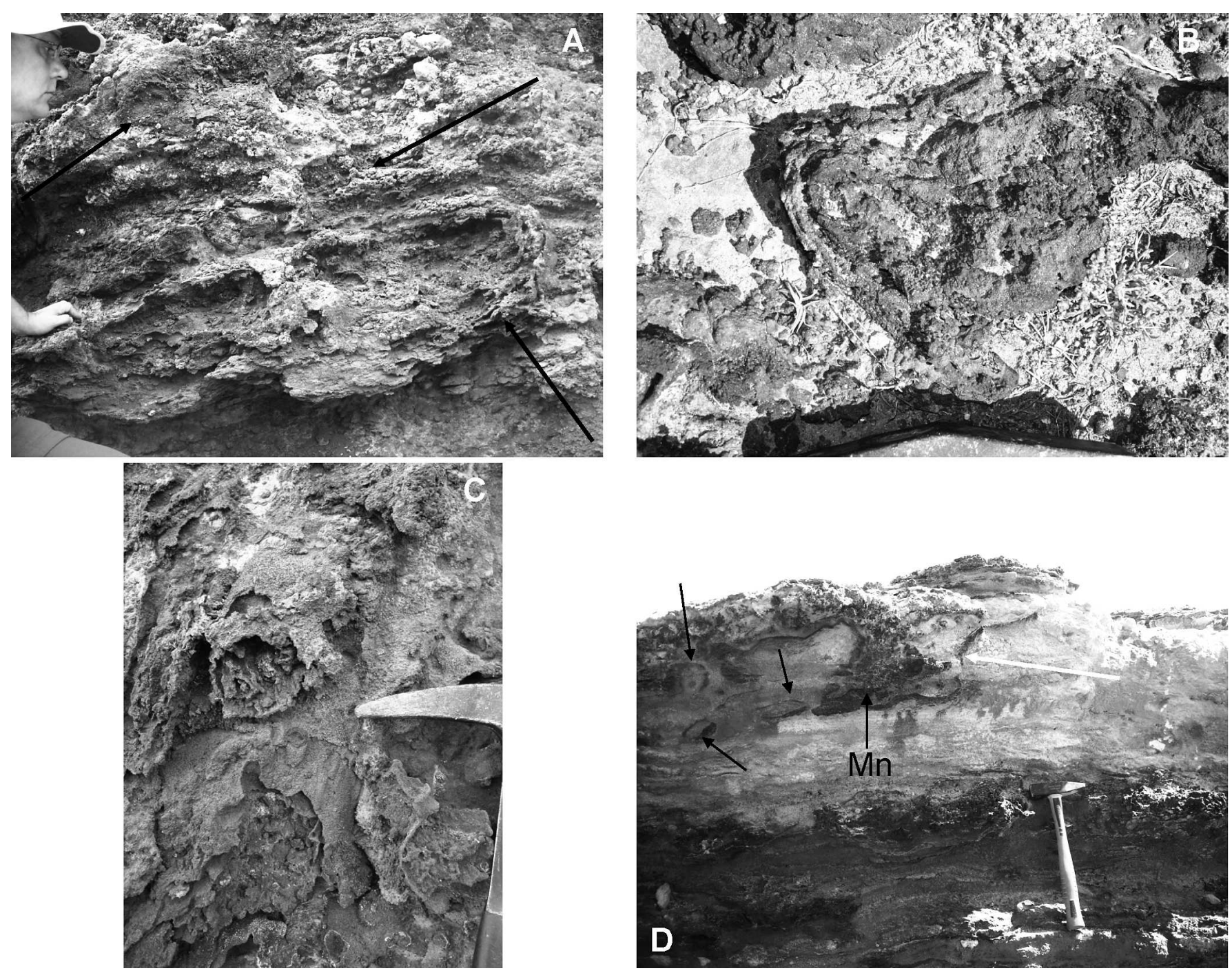

FIG. 8.- Roll-up and mat slump structures. (A) Cross-section of flattened rolled-up fragments (arrows) of Mn sandstone ore. (B) Partly weathered roll-up structure of Mn sandstone ore from upper surface of Mn sandstone bed. Portion of hammer head is $13 \mathrm{~cm}$ long (bottom of photo). (C) Unflattened concentric roll-up consisting of Mn-oxide thin crusts, with elongated cigar-like geometry from Mn cobble deposits; at least three complete concentric layers can be seen. Portion of hammer head is $8 \mathrm{~cm}$ long. (D) Cross-section of stratiform Mn deposits showing compaction load-cast structure (white arrow) of a chaotic "mass-flow"-like unit of coarse-grained Mn sandstone/sandy tuff resting on an irregularly deformed and folded thin Mn-oxide mat layer (Mn)( mat slump structure) interlaminated with thinly bedded tidal Mn sandstone/ sandy tuff; associated rolled-up fragments of Mn-oxide layers are shown by black arrows. Hammer shaft is $35 \mathrm{~cm}$ long.

Cady 2001). (4) Cell division textures: Associations of two or more round-shaped structures and branching are interpreted to represent bacterial cell division (Fig. 11A, C). (5) Colony formation: The great number of discrete clusters is consistent with modern bacterial colony occurrence (Fig. 11A). (6) Pseudomorphosis (Southam and Saunders 2005): Mn-oxide minerals have pseudomorphs after bacteria (Fig. 11A)

Energy dispersive X-ray spectroscopy (EDS) was performed in locations comprising the bacteriomorphous structures; they reveal clear signals for the elements C, O, Mn, Ba, K, and Si (Fig. 11B).

\section{Implication of Microbial Mats for Mn-Oxide Deposition}

The small-scale structures documented here from the Cape Vani Mnoxide deposit reflect growth and decay of microbial mat biomass and interaction with sedimentological and other physical factors (sunlight, temperature, humidity, and nutrients), reaction of benthic microbial mats to erosion and sediment deposition, destruction and deformation of microbial mats, trapping of mineral detritus by the mat surface, and mat surface morphologies and/or internal fabrics (Schieber 2004, Noffke 2010). Taken together, these structures provide good evidence that cohesive microbial mats played important roles during mixed epiclastic/volcaniclastic sediment accumulation in the Cape Vani basin. Moreover, it is suggested that the former microbial mats most probably were constructed by photoautotrophic bacteria, maybe cyanobacteria (Noffke et al. 2006, Noffke 2010).

The intimate relationship of Mn-oxides and microbial matrelated sedimentary structures at the Cape Vani open pit suggests a genetic relationship between microbial, and possibly photoautotro- 

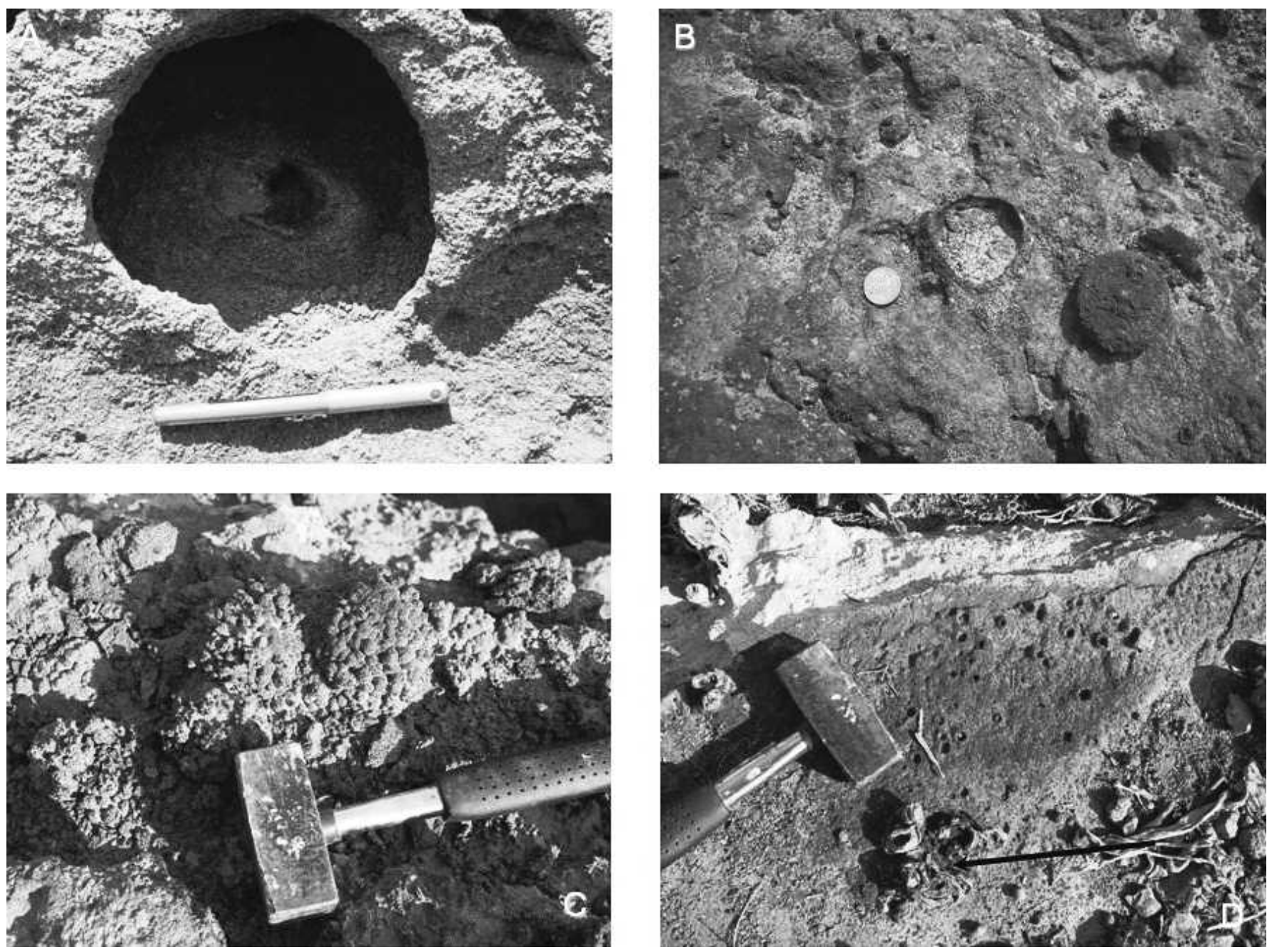

FIG. 9.-Fossil gas domes. (A) Fossil gas dome on Mn sandstone bedding plane. Pen is $14 \mathrm{~cm}$. (B) Fossil gas dome (right of center) with crater; cap of dome exhibits planar laminated structure. Coin is $2 \mathrm{~cm}$ diameter. (C) Domes with nodular and cauliflower-like surfaces. Hammer head is $11 \mathrm{~cm}$ long. (D) Tiny domal features with diameters $<1 \mathrm{~cm}$ on surface of thin $\mathrm{Mn}$ sandstone $/$ sandy tuff bed. Domes may merge into each other and also form oval bodies. Concentric spires coexist on the same bed (arrow). Hammer head is $11 \mathrm{~cm}$ long.

phic, mat growth and Mn-oxide deposition on the paleosediment surface during deposition of the host sediments (e.g., Noffke 2010, Porada and Druschel 2010). Most natural Mn-oxides preserved in geological systems are considered to have been derived either directly as a result of biologically catalyzed $\mathrm{Mn}(\mathrm{II})$-oxidation by bacteria and fungi, or from alteration ("aging") of the biogenic antecedents due to abiotic reactions (see reviews by Tebo et al. 2004). A genetic relationship between fossil microbial mats and Mn mineralization is supported by the intimate association of $\mathrm{Mn}$ mineralized microstructures interpreted as fossil microbial filaments and the coccoid and bacillary microorganisms preserved in them (Fig. 11); for details of the processes involved, see Noffke (2010, and references therein).

It should be stressed that any attempt to document microbial matrelated Mn(IV)-oxide mineralization in Cape Vani should take into consideration the spatial association of the microbial mat structures with low-temperature, exhalative, barite-rich deposits characteristic of seafloor venting (see Cape Vani Deposit section and Fig. 10). This relationship suggests that microbial mats developed in association with white smoker-type hydrothermal seafloor activity, which provided an ample source of reduced Mn(II) (Tebo et al. 2004) in the sunlit shallowwater/tidal-flat paleogeothermal system of Cape Vani.

In light of the evidence presented here, a considerable part of the biogenic Mn ore is synsedimentary and syngenetic. Further, evidence for syngenetic mineralization relates to preconsolidation slumping of Mn-oxide-bearing sediments, and compaction load-cast structures (Fig. 8D). This interpretation is also supported by associated "roll-up" structures. These types of soft sandy sediment deformation structures imply internal cohesive strength and are suggestive of a microbial mat origin (Schieber et al. 2007). In summary, the Mn-oxide mineralization in the Cape Vani deposit is in large measure due to an interplay among shallow-marine/tidal-flat sedimentation, hydrothermal seafloor to subaerial hot spring activity, acting as a Mn(II) source, and active photosynthetic and/or chemotrophic microbial activity. 

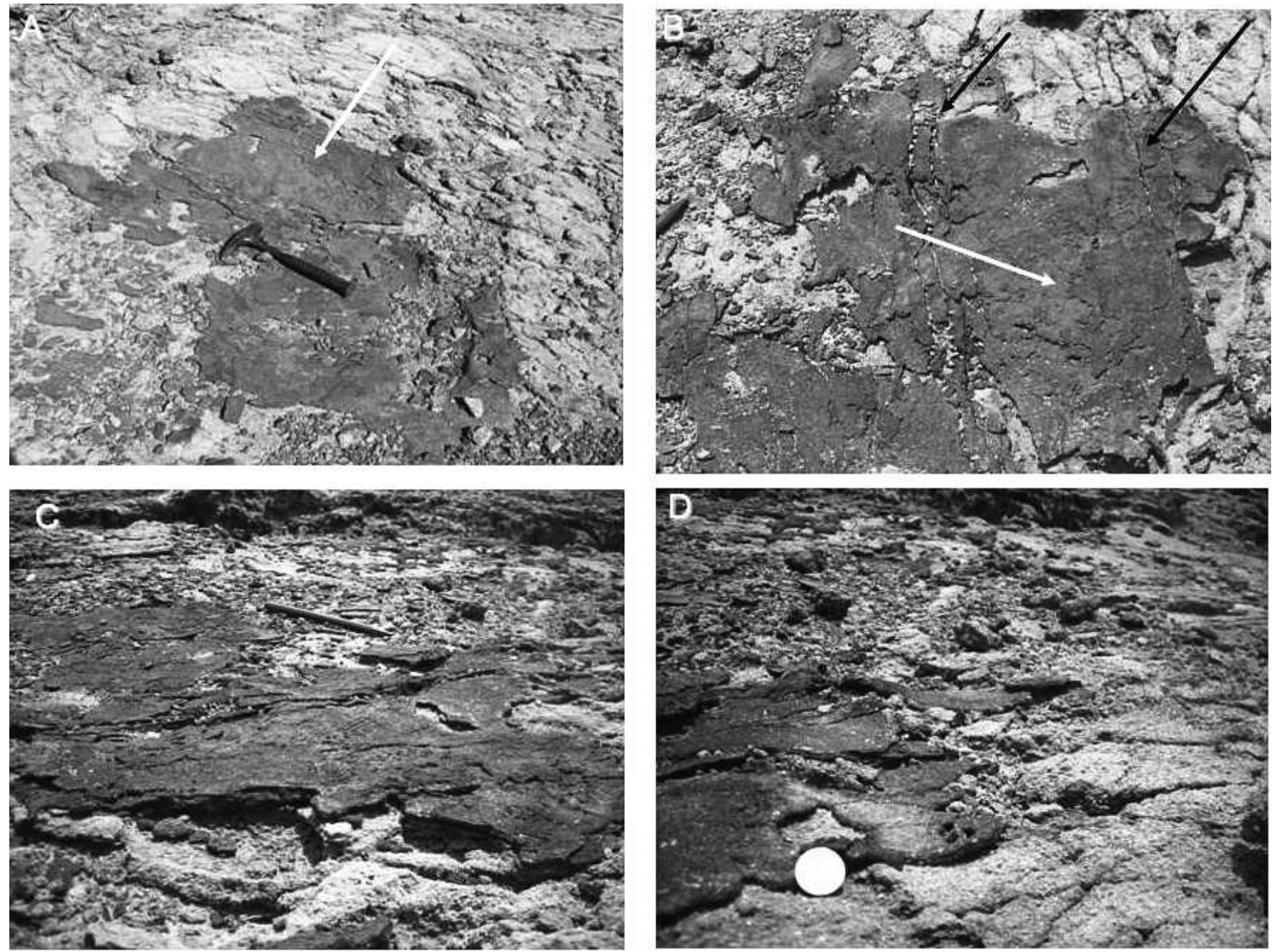

FIG. 10.-Mat fragments and chips. (A, B) Plan view of upper bedding surface of unmineralized sandstone/sandy tuff covered by large patches of millimeter-thick Mn crusts, with highly irregular outlines and embayments, crosscut by white smoker-type hydrothermal-exhalative barite (-silica) feeder veins (black arrows). Exfoliating sand laminae structure is visible (white arrows). Hammer shaft in A is $31 \mathrm{~cm}$ long. Visible part of chisel is $4 \mathrm{~cm}$ long. (C, D) Oblique view of margins of the patchy Mn crusts showing thinly laminated structure and bending. Chisel in $\mathrm{C}$ is $21 \mathrm{~cm}$ long. Coin in D is $2 \mathrm{~cm}$ in diameter.

\section{CONCLUSIONS}

Sedimentary structures interpreted as biotic and microbially induced are developed in the manganese ore formation at the abandoned Cape Vani open-pit mine; they include: (1) mat-layer structures, (2) growth bedding structures and nodules, (3) wrinkle structures and exfoliating sand laminae, (4) cracks with upturned and curled margins, (5) roll-up structures, (6) fossil gas domes, (7) mat fragments and chips, and (8) mat slump structures. The sediments record a shallow-marine to shoreline depositional setting characterized by tidal influence where the various Mn-mineralized, possibly cyanobacterial mats were formed.

The intimate relationship of Mn-oxide ore mineralization and microbially induced sedimentary structures, coupled with the presence of Mn-mineralized microbial body fossils, suggests the possible role of bacterial photosynthesis in $\mathrm{Mn}$ (II) bio-oxidation and Mn(IV)-oxide biomineralization. Most of the Mn(IV)-oxide mineralization was synsedimentary and syngenetic, and formed due to an interplay among shallow-marine/tidal-flat sedimentation, hydrothermal seafloor to subaerial hot spring activity, which provided $\mathrm{Mn}(\mathrm{II})$, and active photosynthetic microbial activity. Chemotrophic influence on Mn(IV)oxide biomineralization cannot be excluded.

\section{ACKNOWLEDGMENTS}

The study was funded by the National and Kapodistrian University of Athens, Athens, Greece (Special Account for Research Grants, project KA 70/4/3373, 70/4/6425, and 70/4/8646). The author deeply appreciates the comments and suggestions of the volume editor, Henry Chafetz, and two other Society for Sedimentary Geology reviewers, David Mossman and Mikael Calner, which improved the final manuscript. This work benefited from comments and encouragement by Nora Noffke. 

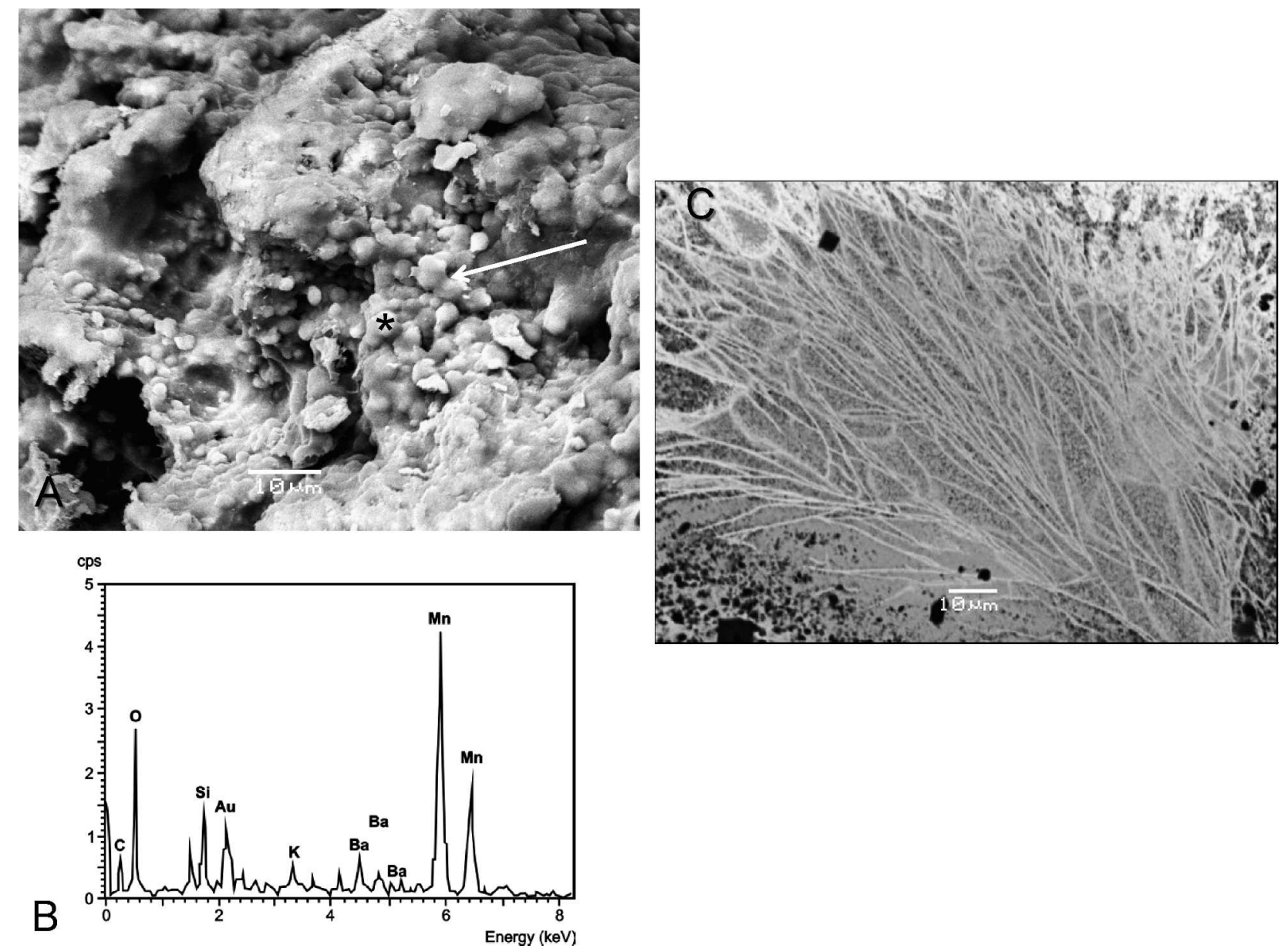

FIG. 11.-SEM-BSE imaging and EDS spectrum of possible body microfossils from Cape Vani. (A) Mn-mineralized bacteriomorphous spherical and rod-like particles set in smooth film-like matrix; arrow shows inferred cell division structure. (B) EDS elemental analysis collected from the location marked by an asterisk in A (Au signal comes from gold coating). C indicates branching filamentous Mn-mineralized fossil microorganisms.

\section{REFERENCES}

Bose S, Chafetz HS. 2009. Topographic control on distribution of modern microbially induced sedimentary structures (MISS): a case study from the Texas coast. Sedimentary Geology 213:136-149.

Bottjer D, Hagadorn JW. 2007. Mat growth features. In Schieber J, Bose PK, Eriksson PG, Banerjee S, Sarkar S, Altermann W, Catuneau O (Editors). Atlas of Microbial Mat Features Preserved within the Siliciclastic Rock Record, Atlases in Geology 2: Elsevier B.V., Amsterdam. p. 53-71.

Bouougri E, Porada H. 2007a. Mat-related features from the terminal Ediacaran Nudaus Formation, Nama Group, Namibia. In Schieber J, Bose PK, Eriksson PG, Banerjee S, Sarkar S, Altermann W, Catuneau O (Editors). Atlas of Microbial Mat Features Preserved within the Siliciclastic Rock Record, Atlases in Geology 2: Elsevier B.V., Amsterdam. p. 214-221.

Bouougri E, Porada H. 2007b. Complex structures associated with siliciclastic biolaminites. In Schieber J, Bose PK, Eriksson PG, Banerjee S, Sarkar S, Altermann W, Catuneau O (Editors). Atlas of Microbial Mat Features Preserved within the Siliciclastic Rock Record, Atlases in Geology 2: Elsevier B.V., Amsterdam. p. 111-115.

Bromley RG, Asgaard U. 1991. Ichnofacies - a mixture of taphofacies and biofacies. Lethaia 24:153-163.

Chafetz HS, Akdim B, Julia R, Reid A. 1998. Mn- and Fe-rich black travertine shrubs; bacterially (and nanobacterially) induced precipitates. Journal of Sedimentary Research 68:404-412.

Chafetz HS, Reid A. 2000. Syndepositional shallow-water precipitation of glauconitic minerals. Sedimentary Geology 136:171-192.

Dashtgard SE, Gingras MK, MacEachern JA. 2009. Tidally modulated shorefaces. Journal of Sedimentary Research 79:793-807.

Dick GJ, Clement BG, Webb SM, Fodrie FJ, Bargar JR, Tebo BM. 2009. Enzymatic microbial $\mathrm{Mn}(\mathrm{II})$ oxidation and $\mathrm{Mn}$ biooxide production in the Guaymas Basin deep-sea hydrothermal plume. Geochimica et Cosmochimica Acta 73:6517-6530.

Donaldson JA, Chiarenzelli JR. 2007. Disruption of mats by seismic events. In Schieber J, Bose PK, Eriksson PG, Banerjee S, Sarkar S, Altermann W, Catuneau O (Editors). Atlas of Microbial Mat Features Preserved within the Siliciclastic Rock Record, Atlases in Geology 2: Elsevier B.V., Amsterdam. p. 245-247.

Dornbos SQ, Bottjer DJ, Chen J. 2004. Evidence for seafloor microbial mats and associated metazoan lifestyles in Lower Cambrian phosphorites of Southwest China. Lethaia 37:127-137.

Eriksson PG, Schieber J, Bouougri E, Gerdes G, Porada H, Banerjee S, Bose PK, Sarkar S. 2007. Classification of structures left by microbial mats in their host sediments. In Schieber J, Bose PK, Eriksson PG, Banerjee S, Sarkar S, Altermann W, Catuneau O (Editors). Atlas of Microbial Mat Features 
Preserved within the Siliciclastic Rock Record, Atlases in Geology 2: Elsevier B.V., Amsterdam. p. 39-105.

Fytikas M, Innocenti F, Kolios N, Manetti P, Mazuolli R, Poli G, Rita F, Villari L. 1986. Volcanology and petrology of volcanic products from the island of Milos and neighbouring islets. Journal of Volcanology and Geothermal Research 28:297-317.

Gerdes G. 2007. Structures left by modern microbial mats in their host sediments. In Schieber J, Bose PK, Eriksson PG, Banerjee S, Sarkar S, Altermann W, Catuneau O (Editors). Atlas of Microbial Mat Features Preserved within the Siliciclastic Rock Record, Atlases in Geology 2: Elsevier B.V., Amsterdam. p. 5-38.

Gerdes G, Klenke T, Noffke N. 2000. Microbial signatures in peritidal siliciclastic sediments: a catalogue. Sedimentology 47:279-308.

Glasby GP, Papavassiliou CT, Mitsis J, Valsami-Jones E, Liakopoulos A, Renner RM. 2005. The Cape Vani manganese deposit, Milos Island, Greece: a fossil stratabound $\mathrm{Mn}-\mathrm{Ba}-\mathrm{Pb}-\mathrm{Zn}-\mathrm{As}-\mathrm{Sb}-\mathrm{W}-$ rich hydrothermal deposit. In Fytikas M, Vougioukalakis GE (Editors). The South Aegean Active Volcanic Arc, Developments in Volcanology 7: Elsevier, Amsterdam. p. 255-288.

Gutzmer J, Schaefer MO, Beukes NJ. 2002. Red bed-hosted oncolitic manganese ore of the Paleoproterozoic Southpansberg Group, Bronkhorstfontein, South Africa. Economic Geology 97:1151-1166.

Harris AC, White NC, McPhie J, Bull SW, Line MA, Skrzeczynski R, Mernagh TP, Tosdal RM. 2009. Early Archean hot springs above epithermal veins, North Pole, Western Australia: new insights from fluid inclusion microanalysis. Economic Geology 104:793-814.

Hedenquist JW, Arribas A, Conzalez-Urien E. 2000. Exploration for epithermal gold deposits. Reviews in Economic Geology 13:245-278.

Hein JR, Schulz MS, Dunham, RE, Stern RJ, Bloomer SH. 2008. Diffuse flow hydrothermal manganese mineralization along the active Mariana and southern Izu-Bonin arc system, western Pacific. Journal of Geophysical Research 113:B08S14. DOI:10.1029/2007JB005432

Hein JR, Stamatakis MG, Dowling JS. 2000. Trace metal-rich Quaternary hydrothermal manganese oxide and barite deposit, Milos Island, Greece. Institute of Mining and Metallurgy Transactions, Section B, Applied Earth Science 109:67-76.

Kilias SP, Detsi K, Godelitsas A, Typas M, Naden J, Marrantos Y. 2007. Evidence of Mn-oxide biomineralization, Vani Mn deposit, Milos, Greece. In Andrew CJ, Annesley I, Archibald S, Beaudoin G, Bierlein FP, Borg G, Boyce A, Broughton D, Canby V, Cleverley J, Clifford J, Cooke D, Cuney M, Frimmel H, Goldfarb R, Groves D, Hageman S, Herrington R, Hofstra A, Huston D, Johnson K, Kerr A, Kouzmanov K, Large D, Large R, Leach D, Lehmann B, Lentz D, McCready A, Meinert L, Misierwicz J, Molnár F, Moritz R, Pasava J, Peter J, Peytcheva I, von Quadt A, Redmond P, Riddler G, Roberts P, Roberts S, Scott P, Stanley G, Stein H, Symons D, Tornos F Wilkinson J, Williams P. (Editors). Digging Deeper, Proceedings of the Ninth Biennial SGA: Irish Association of Economic Geologists, Dublin, Ireland. p. 1069-1072.

Kilias SP, Naden J, Cheliotis I, Shepherd TJ, Constandinidou H, Crossing J, Simos J. 2001. Epithermal gold mineralization in the active Aegean Volcanic Arc: the Profitis Ilias deposit, Milos Island, Greece. Mineralium Deposita 36:32-44.

Liakopoulos A, Glasby GP, Papavassiliou CT, Boulegue J. 2001. Nature and origin of the Vani manganese deposit, Milos, Greece: an overview. Ore Geology Reviews 18:181-209.

Naden J, Kilias SP, Darbyshire DPF. 2005. Active geothermal systems with entrained seawater as modern analogs for transitional volcanic-hosted massive sulphide and continental magmato-hydrothermal mineralization: the example of Milos Island, Greece. Geology 33:541-544.

Noffke N. 2000. Extensive microbial mats and their influences on the erosional and depositional dynamics of a siliciclastic cold water environment (Lower Arenigian, Montagne Noire, France). Sedimentary Geology 136:207-215.

Noffke N. 2010. Geobiology: Microbial Mats in Sandy Deposits from the Archean Era to Today: Springer-Verlag, Berlin. 194 p.

Noffke N, Beukes N, Bower D, Hazen RM, Swift DJP. 2008. An actualistic perspective into Archean worlds - (cyano-) bacterially induced sedimentary structures in the siliciclastic Nhlazatse Section, 2.9 Ga Pongola Supergroup, South Africa. Geobiology 6:5-20.

Noffke N, Eriksson KA, Hazen RM, Simpson EL. 2006. A new window into
Early Archean life: microbial mats in Earth's oldest siliciclastic tidal deposits (3.2 Ga Moodies Group, South Africa). Geology 34:253-256.

Noffke N, Gerdes G, Klenke T, Krumbein WE. 2001. Microbially induced sedimentary structures: a new category within the classification of primary sedimentary structures. Journal of Sedimentary Research 71:649-656.

Noffke N, Knoll A, Grotzinger J. 2002. Sedimentary controls on the formation and preservation of microbial mats in siliciclastic deposits: a case study from the Upper Neoproterozoic Nama Group, Namibia. Palaios 17:533-544.

Ostwald J. 1981. Evidence for a biogeochemical origin of the Groote Eylandt manganese ores. Economic Geology 76:556-567.

Ostwald J. 1990. The biochemical origin of the Groote Eylandt manganese oxide pisoliths and ooliths, northern Australia. Ore Geology Reviews 5:469490.

Pirajno F, Van Kranendonk MJ. 2005. Review of hydrothermal processes and systems on Earth and implications for Martian analogues. Australian Journal of Earth Science 52:329-351.

Plimer I. 2000. Milos Geologic History: Koan Publishing House, Athens, Greece. $261 \mathrm{p}$

Porada H, Bouougri E. 2007. "Wrinkle structures"-a critical review. In Schieber J, Bose PK, Eriksson PG, Banerjee S, Sarkar S, Altermann W, Catuneau O (Editors). Atlas of Microbial Mat Features Preserved within the Siliciclastic Rock Record, Atlases in Geology 2: Elsevier B.V., Amsterdam. p. 135-144.

Porada H, Druschel G. 2010. Evidence for participation of microbial mats in the deposition of the siliciclastic 'ore formation' in the Copperbelt of Zambia. Journal of African Earth Sciences 58:427-444.

Reineck HE, Gerdes G, Claes M, Dunajtschik K, Riege H, Krumbein WE. 1990. Microbial modification of sedimentary surface structures. In Heling D, Rothe P, Foerstner U, Stoffers P (Editors). Sediments and Environmental Geochemistry: Springer-Verlag, Berlin. p. 254-276.

Reysenbach AL, Cady SL. 2001. Microbiology of ancient and modern hydrothermal systems. Trends in Microbiology 9:79-86.

Sarkar S, Banerjee S, Samanta P, Jeevankumar S. 2006. Microbial mat-induced sedimentary structures in siliciclastic sediments: examples from the $1.6 \mathrm{Ga}$ Chorhat Sandstone, Vindhyan Supergroup, MP, India. Journal of Earth System Science 115:49-60.

Sarkar S, Bose PK, Samanta P, Sengupta P, Eriksson PG. 2008. Microbial mat mediated structures in the Ediacaran Sonia Sandstone, Rajasthan, India, and their implications for Proterozoic sedimentation. Precambrian Research 162:248-263.

Schieber J. 1999. Microbial mats in terrigenous clastics: the challenge of identification in the rock record. Palaios 14:3-12.

Schieber J. 2004. Microbial mats in the siliciclastic rock record: a summary of the diagnostic features. In Eriksson PG, Altermann W, Nelson DR, Mueller WU, Catuneau O (Editors). The Precambrian Earth: Tempos and Events, Developments in Precambrian Geology 12: Elsevier, Amsterdam. p. 663 673.

Schieber J, Bose PK, Eriksson PG, Banerjee S, Sarkar S, Altermann W, Catuneau O (Editors). 2007. Atlas of Microbial Mat Features Preserved within the Siliciclastic Rock Record, Atlases in Geology 2: Elsevier, Amsterdam. $311 \mathrm{p}$.

Skarpelis N, Koutles T. 2004. Geology of epithermal mineralization of the NW part of Milos Island, Greece. In Chatzipetros A, Pavlides S (Editors). Proceedings of the 5th International Symposium on Eastern Mediterranean Geology: School of Geology, Aristotelian University of Thessaloniki, Thessaloniki, Greece. p. 1449-1452.

Southam G, Saunders AD. 2005. The geomicrobiology of ore deposits. Economic Geology 100:1067-1083.

Spiro TG, Bargar JR, Sposito G, Tebo BM. 2010. Bacteriogenic manganese oxides. Accounts of Chemical Research 43:2-9.

Stewart AL, McPhie J. 2006. Facies architecture and Late Pliocene-Pleistocene evolution of a felsic volcanic island, Milos, Greece. Bulletin Volcanology 68:703-726

Tebo BM, Bargar JR, Clement BG, Dick GJ, Murray KJ, Parker D, Verity R, Webb SM. 2004. Biogenic manganese oxides: properties and mechanisms of formation. Annual Review of Earth and Planetary Sciences 32:287-328.

Valsami-Jones E, Baltatzis E, Bailey EH, Boyce AJ, Alexander JL, Magganas A, Anderson L, Waldron S, Ragnarsdottir KV. 2005. The geochemistry of fluids 
from an active shallow submarine hydrothermal system: Milos island, Hellenic Volcanic Arc. Journal of Volcanology and Geothermal Research 148:130-151.

Westall F, Folk RL. 2003. Exogenous carbonaceous microstructures in Early Archaean cherts and BIFs from the Isua Greenstone Belt: implications for the search for life in ancient rocks. Precambrian Research 126:313-330. 